\title{
Editorial
}

\section{The impact on country image of the North Africa and Middle East uprisings}

Place Branding and Public Diplomacy (2011) 7, 79-80. doi:10.1057/pb.2011.9

The recent dramatic upheavals in North Africa and the Middle East have gripped the world's attention in a way that has unmistakable echoes of the collapse of communism in 1989. Regimes that previously seemed immune to challenge have been shaken by popular uprisings that would have been almost inconceivable only weeks previously. Galvanized by the unexpectedly abrupt departure of President Ben Ali from Tunisia, pro-democracy protesters dislodged the seemingly unmovable President Mubarak in Egypt. Similar protests have ignited, though with less clear results, in Libya, Bahrain, Syria, Yemen and other Arab nations. What effect, if any, will these developments have on the reputation and image of the countries concerned?

It remains to be seen whether the unprecedented uprisings of early 2011 will have an enduring impact on each country's image, or if perceptions of each country will simply revert to what they were before once the media spotlight turns to a different part of the world.

Much will depend on whether real reform occurs or if the old regimes manage to hold onto power through postponing promised elections and using that breathing space to persecute opposition forces so that attempts at change are stifled. Should the pro-democracy movement peter out thus, with a return to authoritarian rule, then it is unlikely that there will be any positive change in each country's image. As has often been pointed out in the pages of this journal, real radical change is the basis of improvement in country image.

If democracy does take root in the region, then such a historic shift can be expected to lead to significant changes in the country image perceptions held by foreign audiences. Instead of being submerged by a somewhat negative 'Middle East region brand' effect, individual countries will begin to assert their own unique identity. Instead of being monopolized by the image of one political leader, countries will be able to project the full richness and diversity of their respective cultures as Spain has done in the years following the end of the Franco dictatorship in 1975. Spain's transition to democracy and its subsequent cultural renaissance paved the way for it to become one of the countries most often quoted as an example of a successful nation brand. If real political change materializes, there is no reason why the countries of North Africa and the Middle East should not now follow a similarly positive trajectory with regard to how they are perceived by the rest of the world. The obvious caveat, though, is that these countries must avoid the post-dictator, political vacuum chaos of Iraq. 
The formation of country image is a complex process that has been widely studied, primarily in the disciplines of international relations, marketing and tourism. The range of potential image determinants is infinite. This represents both an opportunity and a challenge for the countries of North Africa and the Middle East. It is an opportunity in that there are no limits to the creativity with which nations can attempt to project their identity to the rest of the world. It is a challenge in that the range of uncontrollable image determinants is extremely wide. An illustrative but not exhaustive range of country image formation factors would include word of mouth, national stereotypes, politics, sports performances, personal experience of the country and its people, export brands and the behaviour of the country's citizens.

Unfortunately for most of the countries of North Africa and the Middle East, country image perceptions held by foreign audiences have been dominated and distorted by just one of the range of image formation factors, namely politics, whether that be the personal image of a military dictator or a more diffuse regional image of extremism, terrorism and so on. All the other image formation factors have been overshadowed, resulting in country images that are incomplete, inaccurate and grotesquely skewed in a negative direction. For Egypt and Tunisia, the situation is redressed to some extent by those countries' successful tourism industries. Indeed, it is unlikely that many foreign tourists who have visited Tunisia in the past 20 years are or were aware of the country's leadership and political regime. Certainly, in the non-francophone media, former Tunisian president Ben Ali had a very low profile. On the other hand, President Mubarak of Egypt was and is a more well-known figure globally, although for Egypt as for Tunisia, the predominant image formation factor for many foreign audiences would most likely have been tourism based.

Visiting a country as a tourist may provide only a superficial impression of a country, but at least it allows personal interaction with locals and the host country culture. In the absence of a significant tourist industry, external perceptions of countries such as Libya, Syria or Algeria are mediated to an unhealthy extent by international media organizations. This phenomenon is exacerbated by the striking absence of alternative image formation factors such as sports performances or export brands, image determinants that can play a hugely significant role in country image perceptions. The country image of New Zealand, for example, is powerfully amplified by the All Blacks rugby team, whereas the country image of Japan is tightly linked with globally successful corporate brands such as Sony, Toyota and Toshiba. However, most foreign audiences would struggle to associate any such iconic sports teams or export brands with the countries of North Africa and the Middle East.

The closed nature of one-party states tends to be reflected in a lack of support for the promotion of cultural activities both domestically and internationally. Given the essential role that culture plays - or at least should play - in the formation of country image, this limits the scope for developing positive country image perceptions. Countries of North Africa and the Middle East lack influential cultural organizations such as Germany's Goethe Institute or the United Kingdom's British Council, both of which play an important role in downplaying those two nations' imperialistic past and in projecting and supporting a more cosmopolitan approach to people-to-people relations. This type of soft power projection through public diplomacy has not as yet been embraced by most countries in North Africa and the Middle East. The opportunity to do so now beckons, provided that the revolutionary impulse towards more open societies does not fade away.

Keith Dinnie Academic Editor NHTV Breda University of Applied Sciences, Postbus 3917, 4800 DX Breda, The Netherlands 